\title{
Assessing Perceptions and Attitudes of an Extreme Sports Park
}

\author{
Monica B. Fine \\ Coastal Carolina University \\ Lorie Y. Runion \\ Coastal Carolina University \\ J. Ralph Byington \\ Coastal Carolina University
}

Action sports have been on the rise in the last decade. A new action sports park is considering developing operations on the east coast. The park would include extreme sports such as surfing, wakeboarding, and skating. The park will feature state of the art technologies that produce consistent waves for surfing 12 months a year. With over 10 million surfers worldwide the newest tourist attraction has been deemed appealing to the tourists that flock to the east coast and locals. Other possible amenities at the park include a family waterpark, dining, shopping, and nightlife opportunities. This study examines consumers' perceptions of the new surf park.

Keywords: extreme sports, surf tourism, sports tourism, sports marketing, surfing

\section{INTRODUCTION}

Promoting sports tourism is an important goal of many east coast cities. Sports tourism is defined as specific travel outside of the customer's usual environment for either passive or active involvement in a sport. Basically, the motivation for the travel is primarily the sport. The search for consistent waves is in high demand to the surfing enthusiasts. People who travel to the beach to surf or live close to the water are often disappointed because the waves are very sporadic. Although the east coast has many tourists visit each year, sadly, only a small number are traveling here for the waves. By creating consistent waves of various sizes with an extreme sports park, surfers will travel from miles away to surf. This park would also create a location for competitions. Since surfing competitions are challenging to host since waves are not consistent, the park would create a stable surf setting to allow for better competition conditions. The action sports park would of course cater to the surfers, but it would also appeal to other target markets. The extreme sports park would appeal to the families and teenagers that visit the east coast because the park will offer many different components such as nightlife and dining.

\section{RESEARCH OBJECTIVES}

- Investigate the benefits and statistics of sports tourism. 
- Examine other extreme sports, like skiing and surfing, to compare and also show the effects they've had economically and financially.

- Analyze consumer opinion/attitude toward towards extreme sports.

- Examine the possibilities for an extreme sports park on the east coast

\section{Sports Tourism}

Golf

Many areas on the east coast are known for golf vacation destinations. Golf has become popular not only locally, but also across the world. It is an expanding sport and has substantial effects on the market (Hudson, 2009). Like surfing, the sport of golf has made profits for retailers. There are brands that only make golf clothing and accessories. Golfers are growing by the minute and each one of them is very devoted to the sport. Middle-aged people, as well as retired people, all enjoy playing golf because it is relaxing and doesn't require too much energy like other sports

Many places are realizing how profitable golf is and they want to invest in the sport. Annually, golf attractions cause golfers to contribute over \$20 billion to the economy (Hudson, 2009). Golfers, like surfers, are willing to go the distance to play a certain golf course or compete in a particular golf competition. This high-income target market can also afford the equipment that is required for golf. A driver alone ranges from $\$ 100$ to $\$ 500$ and that's just one of many clubs in a golfer's bag. As of 2008 , it was estimated that there were 59 million golfers worldwide (Hudson, 2009).

\section{Snow Skiing}

In an effort to better understand the opportunities and dimensions of an innovation of the wave park it is imperative for us to discuss the history, dynamics, evolution and characteristics of similar endeavors. To date in the U.S. there exists no equivalent to the proposed wave park but there are certain entities such as ski resorts that are analogous in the respect that they give consumers better access to utilizing contemporary technology in a certain sport sector.

The wave park gives surfers the opportunity to surf more often, with better conditions than ever before. The nature of surfing is that the ability and access to surf is contingent on the uncontrollable factors of the ocean and weather conditions. The sporadic, indeterminate occurrences of wave frequency (average wave period), size, quality, force, shape and surge in the ocean leaves surfers with the constant dilemma of finding places around the world with consistent intervals and break. Although the ability of surfers to be able to interpret the natural fluidity of a certain wave or surf spot is considered by many to be an art-form, there still exists that desire for consistent, quality waves. The wave park looks to offer a consistent, robust, and accessible form of wave riding. As surf legend Laird Hamilton has said "On days without waves, it is like being a dragon slayer with no more dragons".

The invention of the chair lift in 1936 and the subsequent onset of the ski resort industry gave skiing aficionados and the unversed public alike the same sort of accessibility as the wave park could offer surfers. It is under the lens of this parallel that we must study the history and evolution of the ski resort industry.

It is hard to pinpoint the exact date of the invention of skiing. The use of ski technology as a means of transportation and as a tactic of warfare has been documented since the $13^{\text {th }}$ century in Scandinavia. In the $19^{\text {th }}$ century the use of skis began to shift from a solely transportation tool to being used recreationally and for sport. A newspaper in 1843 included an article on the first known public skiing competition in Norway. Skiing was introduced to the United States beginning approximately in 1836 (Revuelta, 2012). With the invention of the ski lift in 1936, a revolutionary era of ski tourism began to develop. Now, more than ever, skiers were able to access elevated and more varied terrain, at less time, and with less hassle. That same year, Union Pacific Railroad unveiled the first ski based tourism resort in Sun Valley, Idaho. The archetype for world-class ski resorts in the U.S. was laid (Revuelta, 2012). The first media images of competitive skiing were intermittent video images from the 1936 Olympic Games in Germany (Fry, 2008). At the end of WWII, increased disposable income, rising automobile ownership, safer, more 
comfortable ski equipment, and easier access to ski resorts resulted in an influx of ski tourism volume and profitability (Ritchie, 2004).

As ski resort development began to propagate, the onset of complementary ski related amenities and attractions began. Resorts invested in lodging, food, nightlife, and entertainment (Ritchie, 2004). The introduction of commercial snow making technology in the 1950's continued the climb of numbers and increased the length of season that resorts were able to operate. The annual number of ski resort visitors in 1979 was over 50 million. In 1984, the number of ski resorts in the United States was 727 (National Ski Area Association, 2008). By the 1999-2000 ski season, annual visits numbered 52.2 million. This was comprised of 7.4 million skiers and 3.6 million snowboarders (Heneved, 2002). The number of annual visits of both snowboarders and skiers has climbed from 70,600 per ski resort in 1985 to 115,100 per resort in 2004. Annual visitor numbers increased, snowboarder numbers increased, but the number of ski areas operating has fallen from 727 areas in 1985 to 481 areas in 2008 (NSAA Demographic Study, 2008).

Researchers have investigated the dropout rate or non-continued participation of beginners picking up either skiing or snowboarding (NSAA, 2008). Their research identified that $85 \%$ of people who pick up skiing or snowboarding as a sport eventually leave the sport. On the flip side, $15 \%$ of people who try either sport will eventually evolve from beginners to core skiing/snowboarding participants (NSAA, 2008).

We also analyzed the demographic characteristics of skiers. First of all, skiing is imprinted in consumer attitudes as a sport for the wealthy, and with good reason. In the 2008 season $72 \%$ of skiers had incomes greater than $\$ 50,000 /$ year and $48 \%$ had income of over $\$ 100,000 /$ year (NSAA, 2008). The real estate development and luxury amenity sectors of resorts have feasted on this demographic, which has only perpetuated an ever increasing dynamic of upscale, large, pricey, sophisticated and increasingly elite sentiments of resort communities and the resorts themselves. The age of participants has steadily increased from an average of 33.2 in 1998 to 36.5 in 2007 (NSAA, 2008). The Baby Boomer generation and their parents make up 33\% of all skiers. The proportion of younger visitors has declined by around $4 \%$. In 2007, the number of skiers and snowboarders made up $4.4 \%$ of the entire U.S. population and hit the slopes an average of 11 times per year. The combined number of skiers and snowboarders was estimated to be about 11.1 million in 2007 (NSAA, 2008).

We can deduct from this study of the evolution of ski resorts that the introduction of new technology, opportunity and exposure to an action sport can greatly shape the entire landscape of the sport and the industry that services its participants.

\section{Extreme Sports}

Extreme sports also known as action sports have recently been growing all over the world. Skateboarding, surfing, wakeboarding, motocross, BMX, and snowboarding are all examples of this quickly growing sport segment. One event that is held for extreme sports is the X-Games. The $2010 \mathrm{X}$ Games 16 was held in Los Angeles County (Weinstein, et al., 2010). The events that were included were skateboarding, BMX (biking motocross), Motocross (Moto X), and rally cars. Economists found the XGames 16 produced about $\$ 50$ million in noticeable benefits for the city. Due to ESPN's exposure of the games to millions of homes it helped the LA economic market and brought awareness to extreme sports. There was a $\$ 12$ million increase due to tourism associated with the X-Games, and at least 58,000 additional visitor days spent in LA due to the event (Weinstein, et al., 2010).

After looking at how economically beneficial the X Games have been for multiple cities it highlights the positive impact an extremes sports park will have. The park has potential for competitions just like the $\mathrm{X}$ Games. Due to the growing demand for extreme sports and the events that come with them, an extremes sports park will be a great addition to the east coast. The X Games financial boost to the LA area and other areas was the proof we needed. 


\section{Adventure Tourism}

The term adventure in itself is acquiescent to an individual's own conception of what it means to them. There is hardly a consensus on what characterizes a true adventure in the collective conscious of our society. There remains a lack of a concise idea in terms of defining what the elemental essence of adventure is across all spectrums of people. However, there are some studies and theories that have tried to characterize the term in a sense broad enough to encompass the most notable components and assemble them cohesively under the umbrella of "adventure". Mortlock (1984) considered the stages inclusive in an adventure. The stages are as follows: (1) The Play stage, characterized by the concept that a person is operating below their abilities, exerting little effort, engaging in minimal involvement mentally, physically and emotionally, and fear and risk are extremely minimal, (2) The Adventure stage, when a person feels in control of the situation but is overcoming an obstacle using their skills and attributes. Fear and unease may appear and the environment and situation is unfamiliar to the person. This is where skills are learned and potential is revealed, (3) The frontier adventure stage, which is slightly beyond stage 2 adventure phase, this is described as "where the action" is. The feeling of commanding the situation is absent and uncertainty, doubt and fear are prevalent. With effort a successful outcome can be achieved. In this phase a successful outcome can imprint the experience on the individuals mind and becomes the heart of the attractiveness of an adventure, (4) The misadventure stage, when the situation can become out of control or beyond the abilities of a person. The outcome can range from slight psychological/physical harm or culminate in death or serious injury. The potential for great life experience value is inherent in this phase but sometimes a participant may swear off the undertaking for the rest of their lives (Mortlock, 1984).

The drive for adventure is an inborn part of a person's character. For the purposes of this research, we define adventure tourism as the act of traveling to a specific location to participate in physical activities and/or to explore and experience new places. For instance, an adventure travel would be planning a trip to Costa Rica specifically to surf or scuba dive. Adventure tourism is also known as adventure travel, and it is a business that is currently growing exponentially since the $1970 \mathrm{~s}$. These travels include safari trips to Africa, backpacking through Europe, and climbing the Himalayas, all which became popular around that time. Today's adventure travel market comprises activities such as backpacking, canoeing, climbing, caving, fly-fishing, kayaking, rafting, safaris, snorkeling, snowboarding, and trekking (Stowell, et. al. 2009). "The value of the global adventure market is $\$ 89$ billion" while this market continues to trend upward (Stowell et. al. 2009). This industry in the US alone is worth an estimated $\$ 8$ billion dollars (Dolnicar and Flunker, 2013).

After surveying regions of North America, Latin America, and Europe, their study found that adventure travelers make up 26 percent of all travelers in the surveyed regions. The average age of an adventure traveler is 40 which is 10 years younger than the average travelers age. Travelers aged 18-44 splurge for once-in-a-lifetime opportunities and seek authentic experiences (Stowell et. al. 2009). "Adventure travel is big business... growth has accelerated at a 65\% yearly rate since 2009" (Canadian Travel Press, 2013). This proves how significant the role of the adventure tourism market is in the travel industry. Adventure tourism is opening doors globally for businesses and organizations as well as allowing them to capitalize on the popularity that adventure travel is so rapidly gaining.

\section{All About Surfing \\ Surfer Demographics}

Research has found that experienced surfers are mostly male (90\%) 34 years old, educated (62\% have a bachelor's degree or above), and employed full time earning \$75,000 per year (Wagner, Nelsen and Walker, 2011). Also interesting is the average surfer has 16 years of experience, surfs early in the morning for 2.5 hours, an average 108 times per year and on each visit will spend an average of $\$ 66$ on items such as food, gas, rental equipment, lodging and/or merchandise (Wagner, Nelsen and Walker, 2011). Recent studies have provided a different picture of the surfing lifestyle. Instead of viewing the avid surfer as a high school graduate with a part time job and no responsibility, surfers tend to be college educated with a full time job and a substantial amount of spendable income. Specifically, on the east 
coast, the median age of surfers is 33 years, $60 \%$ of surfers are educated and $74 \%$ are employed full time making an average of \$50,000 a year (Wagner, Nelsen and Walker, 2011). Surfers on the east coast spend more per surf outing (\$94), however, only make an average of nearly 90 beach visits per year (Wagner, Nelsen and Walker, 2011). Nearly 60\% of surfers prefer waves that are between 4 and 6 feet high (Dolnicar and Flunker, 2003).

\section{Surf Tourism}

Across the world, surfing has become a prominent sport. The surfers in the past decade have been the fuel behind the growth in retailers that cater to the surfing lifestyle because the younger generation has modernized the sport of surfing. There have been many attractions that have come in to play for surfers; this includes magazines, surfing trips, surf lodges, and surf expos. When looking back through the decades, one can easily see the changes and growth in surfing.

Although the last decade has brought about a younger generation to the world of surfing, there are still many surfers that are in their thirties and older. A lot of segments of surf tourism, like lodges and charters, favor those surfers because of their higher income and profitability. Most of these veteran surfers are also people with consistent and successful jobs, so they're able to spend greater amounts on surfing trips. However, that doesn't mean the attractions aimed at younger surfers don't make money. Surf schools and surf trips that cater to the younger generation also generate money because of how many young surfers there are across the world. Surfing is just as popular on the other side of the world as it is here in the United States. In fact, Japan is home to many indoor wave pools (Buckley, 2002). With the innovation of the wave park, surf schools and wave pools are making it easier to learn to teach the public the craft of surfing. Due to the large age range of surfers, surfing has become a lifetime sport. Being able to cater to all ages of surfers will help spur growth in surfing participation.

Surfing has also had a substantial effect on the fashion industry. There are many well-known fashion brands that are known for surfing: like Billabong, Rip Curl, Roxy and Quiksilver. These brands sponsor surfers and even have surf teams. Many surfing campaigns done by these companies have even helped make surfing destinations more popular. Sunglasses brands and surfboard manufacturers also sponsor a lot of the pro and up-and-coming surfers. Not only do these sponsorships help the surfer make more money and travel to more competitions, they also popularize those brands and the sport of surfing. It's a win-win relationship for the surfer and the sponsor. Because of this promotion, more people are getting into the sport of surfing as well as buying the clothing that all of the surfers are wearing.

Media also plays an important role in the sport of surfing. As mentioned above, magazines have played a part in the popularization of surfing. Videos have also helped make surfing more popular and promoted specific surfing destinations (Ponting, 2013). The perfect waves that are shown throughout these surfing magazines and videos cause surfers to dream about going to that spot. The most important thing to surfers is finding the best waves. So when they see an area that has great waves, they immediately want to flock to that place. Surf movies and magazines are exposing places surfers have never seen before and are ultimately creating dreams for these enthusiasts. In conclusion, surfing is growing each year and many are learning how beneficial it can be to invest in the sport. All of the influences and aspects of the sport are creating a large following of devoted fans and surfers. This growth will greatly benefit from the wave pool and is sure to become every surfer's new mecca. Having a surf spot with consistent waves will draw surfers in from miles around. Beginners will be flocking here to learn how to surf and pros will come here to have a day full of surfing large, consistent waves.

\section{Surf Economics}

Research has shown surfers contribute up to $\$ 2$ billion to the U.S. economy each year (Thomas, 2012). Fueled by magazines, videos, competitions, lodges, and tourism this is a vast contribution to the local economies that have embraced surf tourism. According to Ion (2008), the top three places to surf are Jeffrey's Bay (South Africa), Mentawai Islands (Indonesia) and Gold Coast (Australia). There are three things that each of these surfing havens have in common; great weather, beautiful beaches and consistent waves. 
As mentioned previously, overcrowding of the waves and beaches has become an issue in the world of surfing (Ponting, 2013). Surfing is becoming trendier and waves are in high demand. The best surf spots use to be kept a secret and only known by the locals of that area, but that has diminished. Once surfers hear about a place that has good waves, they congregate there. Because of this, overcrowding becomes an issue. Drawing a lot of surfers into an area may be good for its economy in the beginning; however, it could lead to an economic decline. Overcrowding could lead to a decrease in value of the tourists' experience as well as the locals' (Mach, 2009). When surfers and fans start visiting a destination known for its waves, it creates a tourist season for that area. With the creation of the tourist season, the area begins putting more of their focus on the tourists instead of the locals. The shift in focus causes locals to value that area less and they are likely to become irritated with the crowd that the tourism season attracts. Over a period of time, those crowds will wear down the area and the quality will decline. Eventually that destination will have reached its highest numbers of visitors and it will no longer be the favored place to visit when on vacation. This may not be the case for every surf tourist's destination, but it is a common cycle.

Research has shown that over 3 million people in the country surf over 100 times a year (Thomas, 2012). Studies reported a monster surfing spot called Mavericks in California brings $\$ 23.9$ million in each year. In Spain, a wave on the coast at Mundaka is estimated to bring in $\$ 4.5$ million each year to the local economy (Thomas, 2012). From these findings, it really shows the benefits that surfing has had for the economy. Surfers in the past have been looked at as beach bums, but now they're contributing more money to society and therefore, being looked at in a new light. As mentioned previously, the age of surfers varies immensely. However, all of these age groups of surfers make up the total number of surfers in the United States, which amounts to 3.3 million. One focused surfer study showed a majority of the respondents were in their thirties and reported that their household income was over $\$ 75,000$. Nearly $60 \%$ of those respondents had a college education or above (Wagner, Nelson, and Walker, 2011). Table 1 below breaks down the economic impact of these surfers by each region of the United States.

TABLE 1

\section{ECONOMIC IMPACT OF SURFERS}

\begin{tabular}{|l|r|r|r|}
\hline \hline & \multicolumn{1}{|l|}{ Total Visits in Sample } & $\begin{array}{l}\text { Expenditure per visit } \\
(\text { mean) }\end{array}$ & Economic Impact \\
\hline California & $340,305(n=2,315)$ & $\$ 59$ & $\$ 20,077,995$ \\
\hline Florida & $53,130(n=345)$ & $\$ 59$ & $\$ 3,134,670$ \\
\hline Gulf & $9,875(n=79)$ & $\$ 100$ & $\$ 987,500$ \\
\hline Hawaii & $15,259(n=93)$ & $\$ 69$ & $\$ 1,052,871$ \\
\hline Mid-Atlantic & $58,092(n=412)$ & $\$ 94$ & $\$ 5,460,648$ \\
\hline Northeast & $70,625(n=565)$ & $\$ 69$ & $\$ 4,873,125$ \\
\hline Note: "Florida" does not include Gulf coast. Source: Surf-First Surfer Survey, 2009. \\
\hline
\end{tabular}

Since protecting the beach is a valued concern for many, a lot of companies have decided to look into "wave parks" and the effects it could have for the economy (Woody, 2013). Since good waves are not always easy to come by, wave parks can provide the consistency that surfers are looking for in waves. Surf competitions will also benefit. Usually, surf contests last for days or even weeks. The annual Mavericks (in California) big wave competition starts in November and doesn't end until April. Not only is that a long time to wait, but also when the big waves finally do come, surfers are only given a fortyeight hour notice (Woody, 2013). Overall, the constructing of the wave pools and surf parks would embrace the culture of surfing. 


\section{Hypotheses}

H1- As motivation increases, consumers' attitude towards an extreme sports park will increase.

H2- As involvement with action sports increases, consumers' attitude towards an extreme sports park will increase.

H3- As previous experience with action sports increases, consumers' attitude towards an extreme sports park will increase.

H4- As satisfaction of the overall location increases; consumers' attitude towards an extreme sports park will increase.

H5- As gender goes from male to female, consumers' attitude towards an extreme sports park will decrease.

H6- As age increases, consumers' attitude towards an extreme sports park will decrease.

\section{DATA AND METHODOLOGY}

A survey of 36 questions (34 Likert scaled and 2 open-ended) was designed and distributed to nearly 450 consumers. Of the 450 participants, 423 valid responses could be analyzed. From these analyses, we were able to find trends within the data that relate to our dependent variable, the Attitude toward an Extreme Surf Park. First, descriptive statistics were analyzed. Then Pearson correlations were examined between the dependent variable and each of the six independent variables. Finally, multiple regression analysis was used to test the hypothesized relationships (motivation, involvement, experience with action sports, satisfaction of destination, gender and age).

\section{Descriptive}

Table 2 provides descriptive statistics, including mean values, standard deviations, minimums, and maximum for the measurement scales. The mean value for attitude toward the extreme sports park (3.524) denotes a positive impact. Generally, respondents experience positive effects of motivation and involvement (3.80 and 3.14). The majority of the respondents reported by positive effects of experience with action sports (3.48) which was quite surprising. Satisfaction of the overall location was also positive (3.61). The sample consisted of nearly equal proportion of gender (0.54).

TABLE 2

DESCRIPTIVE STATISTICS

\begin{tabular}{|l|r|r|r|r|r|}
\hline & $\mathrm{N}$ & Minimum & Max & Mean & $\begin{array}{c}\text { Std. } \\
\text { Deviation }\end{array}$ \\
\hline DV- Attitude Toward Extreme Sports Park & 423 & 1.0 & 5.0 & 3.524 & 1.1211 \\
Motivation & 423 & 1 & 5 & 3.80 & .881 \\
Involvement & 423 & 1 & 5 & 3.14 & 1.255 \\
Previous Experience with Action Sports & 423 & 1 & 5 & 3.48 & 1.180 \\
Satisfaction of Myrtle Beach & 423 & 1 & 5 & 3.61 & .988 \\
Gender & 423 & 0 & 1 & .54 & .499 \\
Age & 423 & 1 & 6 & 3.52 & 1.499 \\
\hline
\end{tabular}




\section{Correlation Matrix}

Table 3 displays the Pearson coefficients between all variables. The only negatively associated variable with attitude toward an extreme sports park was gender $(-0.187)$. All other variables were positively associated with the attitude toward an extreme sports park. However, only age was not significant. Previous experience with action sports showed the highest correlation at 0.697.

TABLE 3

\section{CORRELATION MATRIX}

\begin{tabular}{|l|r|r|r|r|r|r|r|}
\hline & 1 & 2 & 3 & 4 & 5 & 6 & 7 \\
\hline DV- Attitude Toward & 1 & & & & & & \\
\hline 1. Motivation & $.366^{* *}$ & 1 & & & & & \\
\hline 2. Involvement & $.520^{* *}$ & $.538^{* *}$ & 1 & & & & \\
\hline 3. Previous Experience with & $.697^{* *}$ & $.426^{* *}$ & $.631^{* *}$ & 1 & & & \\
\hline 4. Satisfaction of Myrtle & $.205^{* *}$ & $.356^{* *}$ & $.257^{* *}$ & $.237^{* *}$ & 1 & & \\
\hline 5. Gender & $-.187^{* *}$ & -.088 & $-.231^{* *}$ & $-.265^{* *}$ & -.023 & 1 & \\
\hline 6. Age & .017 & -.059 & -.038 & -.059 & .046 & -.003 & 1 \\
\hline
\end{tabular}

\section{Regression Analysis}

Table 4 shows the results of multiple regression analysis in which attitude toward an extreme sports park is regressed on motivation, involvement, experience with action sports, satisfaction of destination, gender and age. The test of the overall model is $\mathrm{F}=63.725, \mathrm{p}<0.000$. The regression analysis of the factors found positive significance for only previous experience with action sports (beta $=0.589 ; \mathrm{p}=0.000$ ) and involvement (beta $=0.111 ; \mathrm{p}=0.000$ ). All other factors in the model were positive but not significant.

TABLE 4

\section{REGRESSION ANALYSIS}

\begin{tabular}{|l|l|l|}
\hline & Beta (t-value) & Sig \\
\hline Motivation & $.063(1.467)$ & .143 \\
\hline Involvement & $.111(2.190)$ & .029 \\
\hline Previous Experience with Action Sports & $.589(12.496)$ & .000 \\
\hline Satisfaction of Myrtle Beach & $.012(.324)$ & .746 \\
\hline Gender & $.003(.090)$ & .928 \\
\hline Age & $.052(1.453)$ & .147 \\
\hline
\end{tabular}

$R^{2}=.488$, Adjusted $R^{2}=.480$, F-statistic $=63.725$, Significance $=.000, n=407$

\section{DISCUSSION}

The following table (Table 5) shows the hypotheses included in our conceptual model and whether or not they were accepted or rejected after reviewing and analyzing the collected data. 


\section{TABLE 5 \\ HYPOTHESES RESULTS}

\begin{tabular}{|l|l|}
\hline \multicolumn{1}{|c|}{ Hypothesis } & \multicolumn{1}{c|}{ Result } \\
\hline $\begin{array}{l}\text { H1: As motivation increases, attitude towards the } \\
\text { extreme sports park will increase. }\end{array}$ & $\begin{array}{l}\text { This hypothesis was accepted, and it was a } \\
\text { significant relationship according to correlation } \\
\text { analysis, but not significant in the regression } \\
\text { analysis. }\end{array}$ \\
\hline $\begin{array}{l}\text { H2: As Involvement with action sports increases, } \\
\text { attitude towards the extreme sports park will } \\
\text { increase. }\end{array}$ & $\begin{array}{l}\text { This hypothesis was accepted, and it was a } \\
\text { significant relationship in the correlation analysis } \\
\text { and in the regression analysis. }\end{array}$ \\
\hline $\begin{array}{l}\text { H3: As previous experience with action sports } \\
\text { increases, consumers' attitude towards an extreme } \\
\text { sports park will increase. }\end{array}$ & $\begin{array}{l}\text { This hypothesis was accepted, and it was a } \\
\text { significant relationship in the correlation analysis } \\
\text { and in the regression analysis. }\end{array}$ \\
\hline $\begin{array}{l}\text { H4: As satisfaction of the overall location } \\
\text { increases; consumers' attitude towards an extreme } \\
\text { sports park will increase. }\end{array}$ & $\begin{array}{l}\text { This hypothesis was accepted, and it was a } \\
\text { significant relationship according to the } \\
\text { correlation analysis, but not significant according } \\
\text { to the regression analysis. }\end{array}$ \\
\hline $\begin{array}{l}\text { H5: As gender goes from male to female, } \\
\text { consumers' attitude towards an extreme sports } \\
\text { park will decrease. }\end{array}$ & $\begin{array}{l}\text { This hypotheses was significant and negative in } \\
\text { direction according to the correlation analysis, by } \\
\text { not significant in the regression analysis. }\end{array}$ \\
\hline $\begin{array}{l}\text { H6: As age increases, consumers' attitude } \\
\text { towards an extreme sports park will decrease. }\end{array}$ & $\begin{array}{l}\text { This hypothesis was not accepted according to the } \\
\text { correlation analysis or the regression analysis. }\end{array}$ \\
\hline
\end{tabular}

Throughout our quantitative analysis the general conclusions can be found that there is a significant relationship using the variables of involvement, motivation, destination satisfaction, the variety of activities at the park and the dependent variable of attitude towards the extreme sports park. It is important to mention the data shows the respondents have a generally positive attitude towards the extreme sports park. The company pursuing the development of this park should see that people motivated and involved in action sports are very favorable in their attitudes towards the park.

\section{CONCLUSION}

This research study has given us valuable insight into the perceptions and attitudes of the sample towards extreme sports. Through a literature review we described important statistics about the east coast, sports tourism and specific information on surf tourism. In this review we discussed golf tourism, the XGames, ski resort tourism, adventure tourism and finally surf tourism and economy. Researching these topics not only gave us insight into the dynamics of different segments of sports tourism but also made us aware of the type of benefits our park could bring to the area. After distributing a survey we were able to collect data from a population of over 400 people and it helped us to construct an idea of people's thoughts and opinions towards the surf park. More research needs to be done, but there is an excellent start with our study in understanding the viability of this sports park and the target market this organization can begin to focus their marketing efforts towards reaching.

\section{Implications for Managers}

The research study conducted gives valuable insights into the management of this extreme sports park. Factors contributing to the attitudes towards the extreme sports park have been highlighted; a discussion of local residents' perceptions towards a sports park in general have been discussed and the significance of certain variables have been discussed as they pertain to the estimated acceptance and popularity of the extreme sports park. A large proportion of this study focused on low to mid-20 
something college students and their perceptions, attitude and contributing factors in relating to the sports park. This can be a valuable target market for these managers to gain insight from as an extreme sports park will focus a large amount of their energies towards catering towards this market.

\section{REFERENCES}

Amusement Park and Attractions Industry Statistics. (2013). IAAPA.

Beamish, C. (2013). Surf park summit: More surfers, more stoke? Surfline. Retrieved from http://www.surfline.com/surf-news/surf-park-summit-more-surfers-more-stoke 101724/

Bernstein, W. (2013). Statistical Abstract for the Myrtle Beach Area of South Carolina. Myrtle Beach Area Chamber of Commerce. Retrieved February 8, 2014, from http://www.myrtlebeachareachamber.com/research/docs/22statabstract.pdf.

Bernstein, W. (2014). Statistical Abstract for the Myrtle Beach Area of South Carolina. Retrieved from http://www.myrtlebeachareachamber.com/research/docs/23statabstract.pdf

Blevins, J. (2001). Snowboarder Ban Lifted. Retrieved February 26, 2014, http://www.chicagotribune.com/sns-snowboardswelcome-ski011101,0,3005485.story

Boling, P., Prabhu, M. (2013, November 2). Myrtle Beach voters encouraged to support performing arts center referendum. Sun News [Myrtle Beach]. Retrieved February 24, 2014, from http://docs.newsbank.com/s/InfoWeb/aggdocs/AWNB/149D1F46D534E8C8/0D3D15AC6039 3655 ? $p \_$multi $=$MSNB\&s_lang=en-US

Bremner J. (2012). World's 50 best surf spots. Retrieved From http://travel.cnn.com/explorations/play/worlds-50-best-surf-spots-250983

Bryant, D. (2013). Sports competition lures hundreds of teams to myrtle beach. Myrtle Beach Online. Retrieved from http://www.myrtlebeachonline.com/2013/07/19/3594754/sports-competitionlures-hundreds.html

Bryant, D. (n.d.). Sports competition lures hundreds of teams to Myrtle Beach. Retrieved from http://www.myrtlebeachonline.com/2013/07/19/3594754/sports-competition-lures-hundreds.html

Buckley, R. (2002). Surf tourism and sustainable development in indo-pacific islands. Journal of Sustainable Tourism, 10(5), 405-424. Retrieved from http://www98.griffith.edu.au/dspace/bitstream/handle/10072/6732/19530.pdf?sequence=1

Bureau, U. S. (2014). State \& County QuickFacts: USA. U.S. Department of Commerce.

Canadian Travel Press. (2010). Are your clients looking for adventure? Retrieved from http://eds.b.ebscohost.com/eds/pdfviewer/pdfviewer?sid=ed24dd8b-cd7e-480e-bf51de $72 \mathrm{dbc} 20 \mathrm{~d} 89 \% 40$ sessionmgr111\&vid=2\&hid $=110$

Cooper, D. (2001). Myrtle Beach, S.C. National Restaurant News, 35(5), 112-13. Rpt. in Business Work. N.p.: n.p., n.d. N. pag. Print.

Dolnicar, S., \& Flunker, M. (2013). Who's Riding the Wave? An Investigation into Demographic and Psychographic Characteristics of Surf Tourists. Retrieved from http://ro.uow.edu.au/cgi/viewcontent.cgi?article=1258\& context $=$ commpapers

Doyle, C., Durverger, P., Heyniger, C., Lamloureux, K., Martin, N., Schneider, P., \& Stowell, S. (2010). Adventure Tourism Market Report. Retrieved from http://www.adventuretravel.biz/wpcontent/uploads/2010/09/adventure_travel_market0 82610.pdf

Economy in Myrtle Beach, South Carolina. (2013). Economy in Myrtle Beach, SC. Retrieved February 9, 2014, from http://www.bestplaces.net/economy/city/south_carolina/ and February 26, 2014, from Mountain Rider Alliance website: http://www.mrablog.com/ski-resort-ownership-in-northamerica-who-owns-what-part-1/

Fry, J. (2008). Ski Racing on TV - A History. International Skiing History Association. Retrieved from http://skiinghistory.org/news/ ski-racing-tv-history

Garau-Vadell, J., \& Borja-Sole, L. (2008). Golf in mass tourism destinations facing seasonality: a longitudinal study. Tourism Review, 63(2), 16-24. Retrieved from http://elib.tic.edu.vn:8080/dspace/bitstream/123456789/11044/1/2.PDF 
GeoVALS: Connecting Motivations with Geography. (2009). Retrieved February 16, 2014, from Strategic Business Insights website: http://www.strategicbusinessinsights.com/vals/free/200901-GeoVALS.pdf

Gonzalez, E. (n.d.). NMB sports complex construction under way. WMBF News. n. page. Web. Retrieved from http://www.wmbfnews.com/story/20496059/construction-underway-to-multi-million-dollarsports-comple\&xgt

Heneved, E. (2002). Ski and Snowboarding Injuries in the Year 2000 [Lecture notes]. Retrieved February 25, 2014, from Wilderness Medical Society website: http:/www.wms.org/news/ snowboard.asp

Holden, A. (n.d.). Understanding Skiers Motivation using PearcesTravel Career Construct. In Annals of Tourism Research (Vol. 26, pp. 435-438). Elsevier. (Original work published 1999)

Horry County, SC. (n.d.). Horry County Government. Retrieved February 18, 2014, from http://www.horrycounty.org/

Hudson, S. (2009). Golf tourism. In Goodfellow Publishers Limited. Retrieved from http://www.docunator.com/bigdata/1/1367112689_d1e7826373/filegolftourism01.pdf

Igoe, J. (2013). A day in the life of North Myrtle Beach. Sun News, The (Myrtle Beach, SC) n.pag. Retrieved February 24, 2014, from NewsBank on-line database (Access World News).

Ion, A. (2008). 10 of the World's Best Surf Spots. Retrieved From http://www.hotelclub.com/blog/10-ofthe-worlds-best-surf-spots/

Jones, S. (2014). T minus three weeks for debut event at north myrtle beach sports complex. Myrtle Beach Online. Retrieved from http:/www.myrtlebeachonline.com/2014/02/10/4017271/t-minus-threeweeks-for-debut.html

Jones, S. (2014). Think of snowbirds as your neighbors. Sun News, The (Myrtle Beach, SC) n.pag. Retrieved February 24, 2014, from NewsBank on-line database (Access World News).

Lee, A. C. (2011). Great-Value Vacations for the Whole Family. Money, 59-63.

Llangennith, W. (2012). Beach Rush. Economist. n. page. Web. Retrieved from http://www.economist.com/node/21550253

Loftus, G. (2013). Sport Tourism Economic Impact Report. Coastal Carolina University.

Mach, L. (2009). Finding another wave: the need for ecotourism principles in international surf culture. Unpublished raw data, American University, Washington D.C. Retrieved from http://www.american.edu/sis/gep/upload/Leon-Mach.pdf

Mazur, C., \& Wilson, E. (2011). Housing Characteristics: 2010. Retrieved from http://www.census.gov/prod/cen2010/briefs/c2010br-07.pdf

Mortlock, C. (1984) The adventure alternative. Milnthorpe: Cicerone Press.

MYR Passenger Deplanements. (n.d.). Myrtle Beach International Airport. Retrieved February 8, 2014, from http://www.flymyrtlebeach.com/about/passenger-deplanements/

Myrtle Beach. (2013). As Grand Park opens, city reveals more big plans. WMBF News. n. page. Web. Retrieved from http://wmbf.dual.worldnow.com/story/22177063/as-grand-park-opens-cityreveals-more-big-plans

Myrtle Beach Bike Week. (2014). About MBBW - Myrtle Beach Bike Week. Myrtle Beach Bike Week. Retrieved February 8, 2014, from http://www.myrtlebeachbikeweek.com/about-mbbw/

Myrtle Beach Economic Outlook. (n.d.). Myrtle Beach Economy, Myrtle Beach economic outlook, Myrtle Beach economic information. Retrieved February 8, 2014, from https:/www.economy.com/metro/precissnapshot.aspx?g=MMYB\&src=PrecisMetro

Myrtle Beach, SC. (2013). Retrieved February 8, 2014, from http://www.forbes.com/places/sc/myrtlebeach/

Myrtle Beach, SC Income and Careers. (2014). Retrieved February 11, 2014, from USA website: http://www.usa.com/myrtle-beach-sc-income-and-careers.htm221q

National Ski Areas Association: 2007/2008 National Demographic Study. (2008).

Noss, A. (2013). Household Income: 2012. Census.

Passenger stats at Myrtle Beach International Airport show decrease in traffic. - WBTW-TV: News, Weather, and Sports for Florence, SC. (2013, December 11). WBTW News 13. Retrieved 
February 8, 2014, from http://www.wbtw.com/story/24194954/passenger-stats-at-myrtle-beachinternational-airport-show-increase-in-traffic

Pedestrian \& Bicycle Milestones. Bike and Pedestrian Milestones. (n.d.). Retrieved February 18, 2014, from http://www.scdot.org/getting/bikePed milestone01.aspx\#milestone01

Ponting, J. (2013). PERFORMANCE, AGENCY AND CHANGE IN SURFING TOURIST SPACE. Annals of Tourism Research: n. page. Web. Retrieved February 11, 2014, from http://www.sciencedirect.com/science/article/pii/S0160738313000947

PR, N. (2014). On The Horizon In 2014 \& Beyond: New Tourism Developments In The Myrtle Beach Area Of South Carolina. PR Newswire US.

Renouf, N. K. (2000). The Carolinas \& the Georgia coast. Edison, N.J.: Hunter. 447. Print.

Revuelta, R. (2012, May 16). Mod. 3: The Evolution of Ski Resorts. Retrieved February 10, 2014, from Ski Paradise website: http://www.slideshare.net/SkiParadise/ essentials-of-tourism-destinationmanagement-the-evolution-of-ski-resorts/

Ritchie, B. W., \& Adair, D. (2004). Evolution of the Market. In B. W. Ritchie \& D. Adair (Eds.), Sports Tourism: Interrelations, Impacts and Issues (pp. 78-79). Tonawanda, NY: Channel View Publications.

Rodriguez, J. M. (2014). Legislators: Fix South Carolina transportation department before thinking tax. Access World News, Sun News, The (Myrtle Beach, SC). Retrieved February 16, 2014, from http://infoweb.newsbank.com/iw-

search/we/InfoWeb?p_action=doc\&p_topdoc=1\&p_docnum=1\&p_sort=YMD_date:D\&p_produ $\mathrm{ct}=$ AWNB\&p_text_direct $0=$ document $\mathrm{id}=(\% 2014 \mathrm{~B} 3 \mathrm{BEA} 801 \mathrm{E} 8 \mathrm{AD} 90 \% 20) \& \bar{p} \_\mathrm{docid}=1$

Sales Tax Overview. (n.d.). Riding on A Penny. Retrieved February 18, 2014, from http://www.ridingonapenny.com/

Skyes, H. (2011). Ski Resort Ownership in North America: Who Owns What, Part 1.

Smith, B. (2013) Beaches and boardwalks: Five free things in Myrtle Beach. Associated Press, Toronto Star (Canada).

South Carolina Community Profiles. (2014). Retrieved February 10, 2014, http://www.sccommunityprofiles.org/

State \& County Quickfacts [Fact sheet]. (2014, January 6). Retrieved February 10, 2014 http://quickfacts.census.gov/qfd/states/45/45051.html

The Associated, P. (2012). Tourists coming to Myrtle Beach on a budget. AP Regional State Report South Carolina

The Associated, P (2013). Burroughs \& Chapin purchases Barefoot Landing. AP Regional State Report South Carolina.

The Associated, P. (2013). Dreary April kept tourists away from Myrtle Beach. AP Regional State Report -South Carolina

The History of USA Ski Resorts [Video file]. (2013, July 3). Retrieved from http://unofficialnetworks.com/video-history-usa-ski-resorts-skier-visits-5-million-3-million$83227 /$

The World Factbook. (2014). The World Factbook. Central Intelligence Agency.

Thomas, G. (2012). Surfonomics quantifies the worth of waves. Washington Post: n. page. Web. Retrieved February 11, 2014, from http://www.washingtonpost.com/surfonomics-quantifies-theworth-of-waves/2012/08/23/86e335ca-ea2c-11e1-a80b9f898562d010_story.html?socialreader_check=0\&denied $=1$

Trend of Median Household Income. (2012). Retrieved February 16, 2014, from Strategic Business Insights website: http://www.strategicbusinessinsights.com/vals/free/201207medhhincbyvals.shtml

Tucker, B. (2013). Destination guide: The golf courses of myrtle beach and the grand strand. Retrieved from http://www.worldgolf.com/golf-destinations/myrtlebeach/myrtle-beach-golf.htm

US Framework and VALSTM Types. (2014). Retrieved February 16, 2014, from Strategic Business Insights website: http://www.strategicbusinessinsights.com/vals/ustypes.shtml 
Verpa, J., Lewis, J. M., \& Kreider, R. M. (2013). America's Families and Living Arrangements: 2012. Cenus.

Visit Myrtle Beach. (2014). Driving distances. Retrieved from http://www.visitmyrtlebeach.com/about/transportation/driving-distances/

Visit Myrtle Beach South Carolina. (2019). Myrtle Beach Area Convention and Visitors Burea, 2014. Web. Retrieved February 10, 2014, from http://www.visitmyrtlebeach.com/things-todo/events/festivals/

Visit North Myrtle Beach. (2014). North Myrtle Beach Sports Tourism. n. page. Web. Retrieved from http://www.northmyrtlebeachchamber.com/index.php?src=gendocs\&ref=SportsTourism\&categor $\mathrm{y}=$ Main

Wagner, G. S., Nelsen, C., \& Walker, M. (2011). A socioeconomic and recreational profile of surfers in the united states. In W. Surf-First \& W. Surfrider Foundation (Eds.),

Wagner, S., Nelsen, C., \& Walker, M. (2011). A socioeconomic and recreation profile of surfers in the united states. Retrieved from http://public.surfrider.org/files/surfrider_report_v13.pdf

Weinstein, R., DeGracia, J., \& Lin, E. (2010) Economic Impact of the 2010 X Games 16 on Los Angeles County. Retrieved from http://www.micronomics.com/articles/xgames.pdf

WMBF News Staff. (2013) crimes increase in Myrtle Beach. 26 Feb. 2014. Web. Retrieved March 20, 2014, from http://www.wmbfnews.com/story/24807795/2013-violent-property-crimes-increasein-myrtle- beach

WMBF. (2013, May 6). Myrtle beach: As grand park opens, city reveals more big plans. Retrieved from http://wmbf.dua1.worldnow.com/story/22177063/as-grand-park-opens-city-reveals-more-bigplans

Woody, T. (2013). The next big thing in surfing is artificial waves you can ride anywhere, any time. Quartz. Retrieved from http://qz.com/159789/the-next-big-thing-in-surfing-is-artificial-wavesyou-can-ride-anywhere-any-time/

Yusoontorn, S. (2012). 66 Quotes on Marketing from Philip Kotler. Retrieved March 22, 2014 from http://www.slideshare.net/bright9977/66-quotes-on-marketing-from-philip-kotler 